\title{
Nanometer Confinement Induces Nematic Order in 1-Dodecanol
}

\begin{abstract}
Antonela Ananiadou, ${ }^{a}$ George Papamokos, ${ }^{a}$ Martin Steinhart ${ }^{\mathrm{c}}$ and George
\end{abstract} Floudas ${ }^{* a, b}$

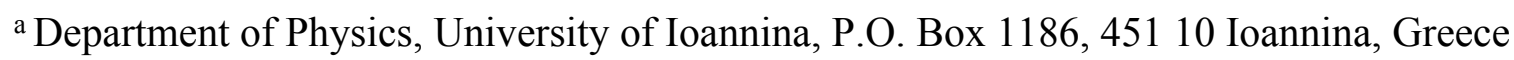

b University Research Center of Ioannina (URCI) - Institute of Materials Science and Computing, Ioannina, Greece

${ }^{\mathrm{c}}$ Institut für Chemie neuer Materialien, Universität Osnabrück, D-49069 Osnabrück, Germany 


\section{Cartesian coordinates}

A. 1-dodecanol all trans

\begin{tabular}{|c|c|c|c|}
\hline $\mathrm{C}$ & 6.37864700 & 0.43103800 & -0.00000300 \\
\hline $\mathrm{H}$ & 6.39585100 & 1.08145000 & 0.89233800 \\
\hline $\mathrm{H}$ & 6.39584500 & 1.08144100 & -0.89235100 \\
\hline $\mathrm{C}$ & 5.11439700 & -0.40794100 & 0.00000400 \\
\hline $\mathrm{H}$ & 5.12750000 & -1.06385200 & 0.88325300 \\
\hline $\mathrm{H}$ & 5.12750000 & -1.06386600 & -0.88323400 \\
\hline $\mathrm{C}$ & 3.84615900 & 0.44257200 & -0.00000200 \\
\hline $\mathrm{H}$ & 3.84479800 & 1.10399900 & 0.88172500 \\
\hline $\mathrm{H}$ & 3.84480000 & 1.10398800 & -0.88173700 \\
\hline $\mathrm{C}$ & 2.56809400 & -0.39313700 & 0.00000100 \\
\hline $\mathrm{H}$ & 2.56706300 & -1.05486700 & -0.88111800 \\
\hline $\mathrm{H}$ & 2.56706400 & -1.05486200 & 0.88112400 \\
\hline $\mathrm{C}$ & 1.29492100 & 0.44941800 & 0.00000000 \\
\hline $\mathrm{H}$ & 1.29648100 & 1.11146800 & 0.88124400 \\
\hline $\mathrm{H}$ & 1.29648200 & 1.11146700 & -0.88124600 \\
\hline $\mathrm{C}$ & 0.01674200 & -0.38574000 & 0.00000000 \\
\hline $\mathrm{H}$ & 0.01508800 & -1.04785300 & 0.88108600 \\
\hline $\mathrm{H}$ & 0.01508700 & -1.04785100 & -0.88108900 \\
\hline $\mathrm{C}$ & -1.25702100 & 0.45611800 & 0.00000100 \\
\hline $\mathrm{H}$ & -1.25526700 & 1.11826100 & -0.88114800 \\
\hline $\mathrm{H}$ & -1.25526800 & 1.11825600 & 0.88115500 \\
\hline $\mathrm{C}$ & -2.53524600 & -0.37896100 & -0.00000100 \\
\hline $\mathrm{H}$ & -2.53681100 & -1.04112400 & 0.88110500 \\
\hline $\mathrm{H}$ & -2.53681200 & -1.04111700 & -0.88111200 \\
\hline $\mathrm{C}$ & -3.80908900 & 0.46279400 & 0.00000200 \\
\hline $\mathrm{H}$ & -3.80703200 & 1.12496800 & -0.88121100 \\
\hline $\mathrm{H}$ & -3.80703200 & 1.12496100 & 0.88121900 \\
\hline $\mathrm{C}$ & -5.08743500 & -0.37182500 & -0.00000100 \\
\hline $\mathrm{H}$ & -5.08954700 & -1.03431900 & 0.88117300 \\
\hline $\mathrm{H}$ & -5.08954700 & -1.03431400 & -0.88117800 \\
\hline $\mathrm{C}$ & -6.36170700 & 0.47027300 & 0.00000100 \\
\hline $\mathrm{H}$ & -6.35719200 & 1.13128700 & -0.88084500 \\
\hline $\mathrm{H}$ & -6.35719200 & 1.13128300 & 0.88085000 \\
\hline $\mathrm{C}$ & -7.63497700 & -0.37211800 & -0.00000100 \\
\hline $\mathrm{H}$ & -7.67828300 & -1.01974500 & 0.88764300 \\
\hline $\mathrm{H}$ & -8.53369800 & 0.25896900 & 0.00000000 \\
\hline $\mathrm{H}$ & -7.67828200 & -1.01974200 & -0.88764800 \\
\hline $\mathrm{O}$ & 7.49806500 & -0.44609000 & -0.00000400 \\
\hline $\mathrm{H}$ & 8.30297400 & 0.07547800 & 0.00003000 \\
\hline $\mathrm{H}$ & -8.55775900 & 0.24371800 & 0.00001200 \\
\hline $\mathrm{H}$ & -7.68615800 & -1.02947600 & -0.89062000 \\
\hline $\mathrm{O}$ & 7.51765200 & -0.45884000 & 0.00000700 \\
\hline $\mathrm{H}$ & 8.32456500 & 0.07311800 & 0.00001000 \\
\hline
\end{tabular}

B. 1-dodecanol -- C-C-C-O gauche

$\begin{array}{lrrr}\mathrm{C} & 6.47500800 & -0.06140500 & -0.27066900 \\ \mathrm{H} & 6.48664400 & 0.27711600 & -1.32213800 \\ \mathrm{H} & 7.31497400 & -0.76207900 & -0.12814000 \\ \mathrm{C} & 5.16349600 & -0.76533800 & 0.02790800 \\ \mathrm{H} & 5.16612700 & -1.07641500 & 1.08381400 \\ \mathrm{H} & 5.12584500 & -1.68570000 & -0.57591100 \\ \mathrm{C} & 3.92991100 & 0.08875800 & -0.25667400 \\ \mathrm{H} & 3.98908700 & 1.01591700 & 0.33073300 \\ \mathrm{H} & 3.93448000 & 0.38953100 & -1.31744200 \\ \mathrm{C} & 2.62272300 & -0.63438200 & 0.05768700 \\ \mathrm{H} & 2.56900900 & -1.56749800 & -0.52722900 \\ \mathrm{H} & 2.62113900 & -0.93615700 & 1.11774500 \\ \mathrm{C} & 1.38243600 & 0.20946200 & -0.22626500 \\ \mathrm{H} & 1.43585600 & 1.14122600 & 0.35967100 \\ \mathrm{H} & 1.38371400 & 0.51302700 & -1.28588500 \\ \mathrm{C} & 0.07390200 & -0.51100400 & 0.08963700 \\ \mathrm{H} & 0.07264800 & -0.81434000 & 1.14924900 \\ \mathrm{H} & 0.02113200 & -1.44322600 & -0.49615800 \\ \mathrm{C} & -1.16648600 & 0.33287000 & -0.19408700 \\ \mathrm{H} & -1.16520900 & 0.63634900 & -1.25369800\end{array}$




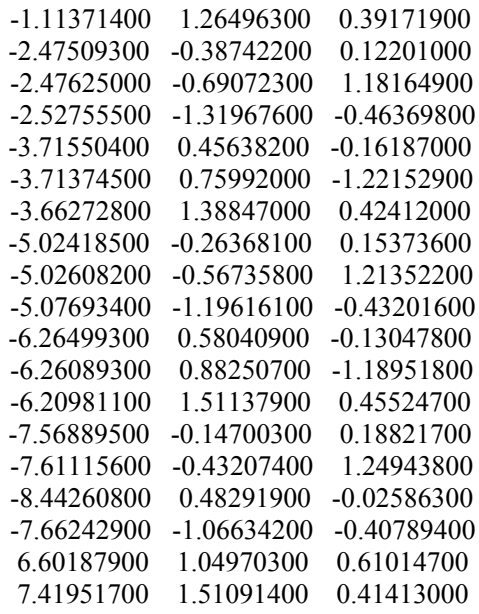

\section{1-dodecanol -- C-C-C-O and C-C-C-C gauche}

$\begin{array}{llll}\mathrm{C} & -6.37608700 & 0.20539800 & 0.36243100\end{array}$

$\begin{array}{lll}-6.33099900 & 0.91401200 & 1.20870200\end{array}$

$\begin{array}{lll}-7.24501800 & -0.45633200 & 0.51698600\end{array}$

$\begin{array}{lll}-5.10356600 & -0.62121600 & 0.31614600\end{array}$

$\begin{array}{lll}-5.16205500 & -1.30512500 & -0.54440200\end{array}$

$\begin{array}{lll}-5.07184300 & -1.24854600 & 1.22087800\end{array}$

$\begin{array}{lll}-3.83028700 & 0.21704700 & 0.22514600\end{array}$

$\begin{array}{lll}-3.88299900 & 0.85856500 & -0.66583200\end{array}$

$\begin{array}{lll}-3.77873700 & 0.89290400 & 1.09478200\end{array}$

$\begin{array}{lll}-2.56338300 & -0.63291100 & 0.17019500\end{array}$

$\begin{array}{lll}-2.51661700 & -1.28109800 & 1.06091300\end{array}$

$\begin{array}{lll}-2.61761300 & -1.30879900 & -0.69871500\end{array}$

$\begin{array}{lll}-1.28393300 & 0.19559400 & 0.08315200\end{array}$

$\begin{array}{llll}-1.33082800 & 0.84267500 & -0.80760200\end{array}$

$\begin{array}{lll}-1.22912400 & 0.87246000 & 0.95135700\end{array}$

$\begin{array}{lll}-0.01548600 & -0.65218400 & 0.02473400\end{array}$

$\begin{array}{lll}-0.06965000 & -1.32801500 & -0.84423000\end{array}$

$\begin{array}{lll}0.03030800 & -1.30057800 & 0.91494500\end{array}$

$\begin{array}{llll}1.26390400 & 0.17667400 & -0.06068900\end{array}$

$\begin{array}{lll}1.31800600 & 0.85235300 & 0.80843200\end{array}$

$\begin{array}{llll}1.21812100 & 0.82526800 & -0.95066600\end{array}$

$2.53264300 \quad-0.67054900 \quad-0.11981800$

$\begin{array}{lll}2.47757400 & -1.34810200 & -0.98739200\end{array}$

$\begin{array}{rrrr}2.57987100 & -1.31726000 & 0.77159800\end{array}$

$\begin{array}{llll}3.81169100 & 0.15885200 & -0.20734900\end{array}$

$\begin{array}{llll}3.85085600 & 0.84321700 & 0.65380100\end{array}$

$\begin{array}{llll}3.77269600 & 0.79542900 & -1.10683900\end{array}$

$\begin{array}{lll}5.07735200 & -0.69637600 & -0.25171700\end{array}$

$\begin{array}{lll}4.98089500 & -1.42964100 & -1.06775800\end{array}$

$\begin{array}{lll}5.15112800 & -1.28075000 & 0.68038300\end{array}$

$\begin{array}{llll}6.37005900 & 0.09860100 & -0.45209800\end{array}$

$\begin{array}{llll}6.31263000 & 0.64562300 & -1.40654500\end{array}$

$\begin{array}{lll}7.20652100 & -0.60897500 & -0.55190600\end{array}$

$\begin{array}{llll}6.67828100 & 1.07934900 & 0.67889200\end{array}$

$\begin{array}{lll}6.70216700 & 0.56211000 & 1.64949600\end{array}$

$\begin{array}{llll}7.65479700 & 1.55891600 & 0.52994600\end{array}$

$\begin{array}{llll}5.92561400 & 1.87665200 & 0.74214900\end{array}$

$\begin{array}{llll}-6.50228800 & 0.90930600 & -0.86845100\end{array}$

$\begin{array}{llll}-7.29451700 & 1.44890800 & -0.83902200\end{array}$

$\begin{array}{rrrr}\text { D. } & \text { 1-dodecanol } & - & \text { C-C-C-O and C-C-C-C eclipsed } \\ \text { C } & -6.38602600 & 0.07124900 & 0.26519800 \\ \text { H } & -6.38885200 & 0.21689100 & 1.36024500 \\ \text { H } & -7.26142900 & -0.54545800 & 0.00039700 \\ \text { C } & -5.11195900 & -0.63908600 & -0.15545500 \\ \text { H } & -5.12198300 & -0.75586400 & -1.24998600 \\ \text { H } & -5.12964100 & -1.65317600 & 0.27394500 \\ \text { C } & -3.83651100 & 0.08144000 & 0.27616300 \\ \text { H } & -3.84123900 & 1.10116000 & -0.13411400 \\ \text { H } & -3.83319200 & 0.18577000 & 1.37381400\end{array}$




$\begin{array}{rrr}-2.56762800 & -0.64284400 & -0.16637500 \\ -2.56857900 & -1.66787700 & 0.23985700 \\ -2.57399300 & -0.74758000 & -1.26355500 \\ -1.28613000 & 0.06739600 & 0.26293600 \\ -1.28598700 & 1.09186700 & -0.14306300 \\ -1.27837800 & 0.17237500 & 1.36015100 \\ -0.01563700 & -0.65226800 & -0.18319200 \\ -0.02372400 & -0.75735900 & -1.28033100 \\ -0.01591500 & -1.67702300 & 0.22285100 \\ 1.26581200 & 0.05889300 & 0.24491200 \\ 1.27461800 & 0.16341400 & 1.34216600 \\ 1.26538900 & 1.08378200 & -0.16048400 \\ 2.53652800 & -0.65940700 & -0.20265200 \\ 2.52908800 & -0.76119600 & -1.30020300 \\ 2.53582400 & -1.68536600 & 0.20022500 \\ 3.81784200 & 0.05105000 & 0.22744000 \\ 3.83388400 & 0.14081400 & 1.32633900 \\ 3.80343600 & 1.07886800 & -0.16606500 \\ 5.08454000 & -0.66702900 & -0.23634400 \\ 5.10063800 & -0.69515200 & -1.33846400 \\ 5.03983600 & -1.71554700 & 0.09758900 \\ 6.38651900 & -0.04198700 & 0.27103300 \\ 7.22822100 & -0.67466300 & -0.04761700 \\ 6.38845900 & -0.05708100 & 1.37254300 \\ 6.62246100 & 1.38641300 & -0.21883300 \\ 5.86772300 & 2.08092400 & 0.17379800 \\ 7.60666300 & 1.75496600 & 0.09940900 \\ 6.58432600 & 1.43464200 & -1.31717500 \\ -6.44446500 & 1.32693600 & -0.40289300 \\ -7.23834500 & 1.78946500 & -0.12812000\end{array}$




\section{POM}

a

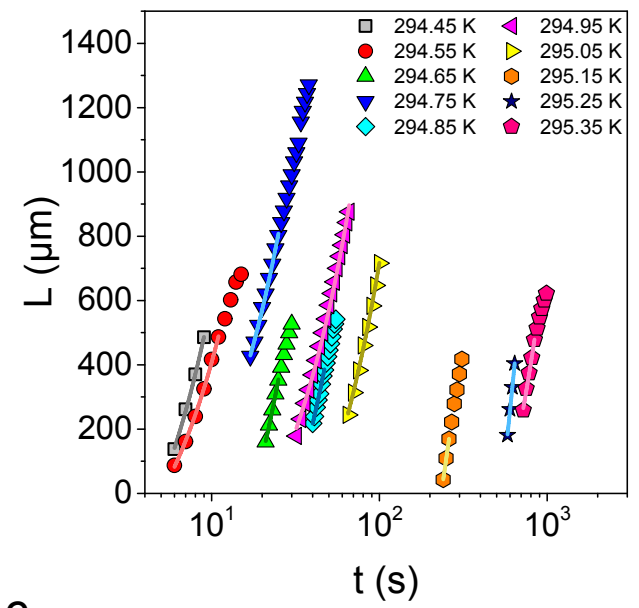

C

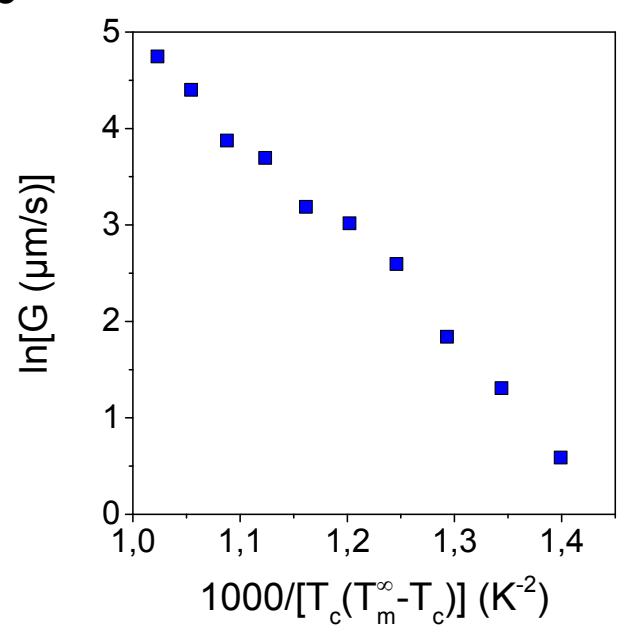

b
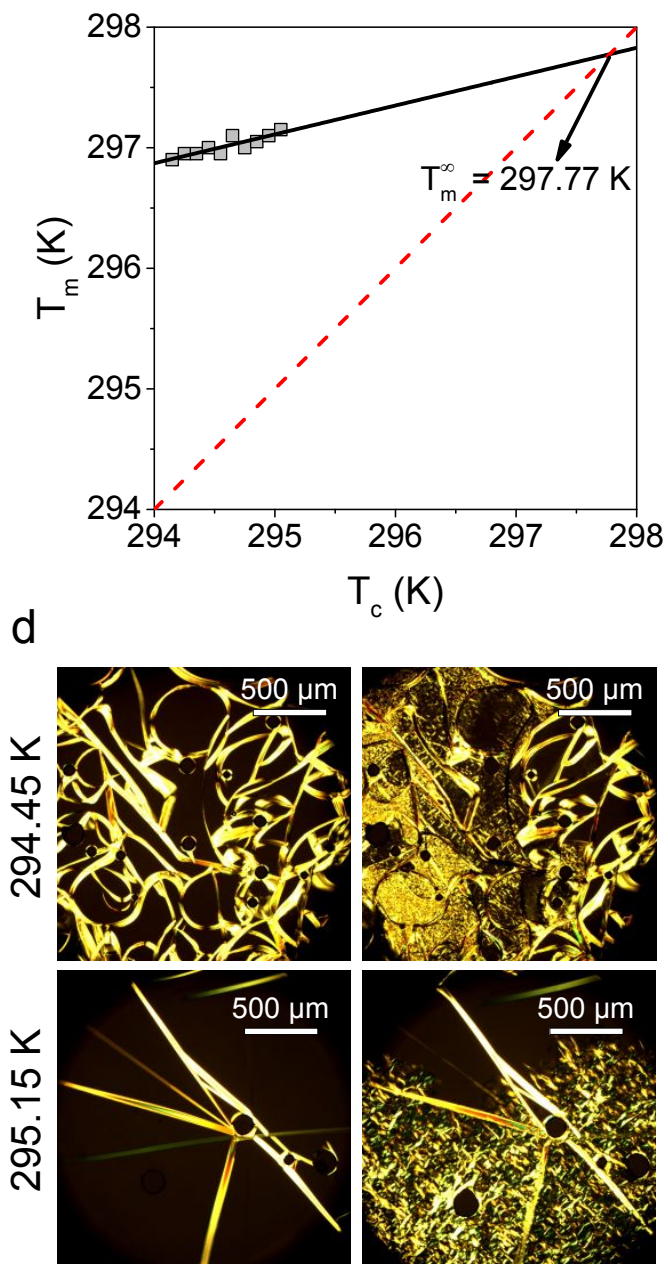

Figure S1. (a) Axialite length as a function of time at different final crystallization temperatures (as indicated), obtained isothermally following quenching from the melt state. Respective lines represent linear fits to the initial slopes. (b) Apparent melting temperatures for different final crystallization temperatures. The equilibrium melting temperature (indicated with the arrow) is estimated from a linear extrapolation. (c) Growth rates of $\alpha$-phase axialites as a function of inverse crystallization temperature and quench depth. (d) POM images at two temperatures, $294.45 \mathrm{~K}$ (top) and $295.15 \mathrm{~K}$ (bottom), corresponding to the $\alpha$-phase (left) and the $\gamma$-phase (right). The scale bars indicate $500 \mu \mathrm{m}$.

POM measurements were made by quenching from the melt to different final temperatures (from $T=294.45 \mathrm{~K}$ to $T=295.35 \mathrm{~K}$ with a temperature interval of $0.1 \mathrm{~K}$ ). At the two highest temperatures (295.25 K and $295.35 \mathrm{~K}$ ) only the $\alpha$-phase was formed. At lower temperatures the $\alpha$-phase was transformed into the $\gamma$-phase. POM images were obtained while observing the evolution of anisotropic structures (axialites) that were curved, in general. The axialites appear to develop some curvature 
(vertical to the observation plane) at longer times. Growth rates within the $\alpha$-phase were obtained from the initial stages of growth (Figure S1a).

\section{Dielectric Permittivity}

a

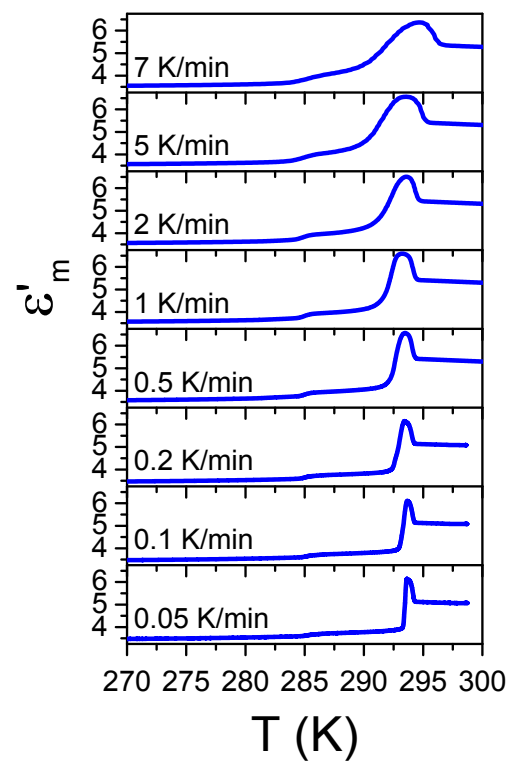

b

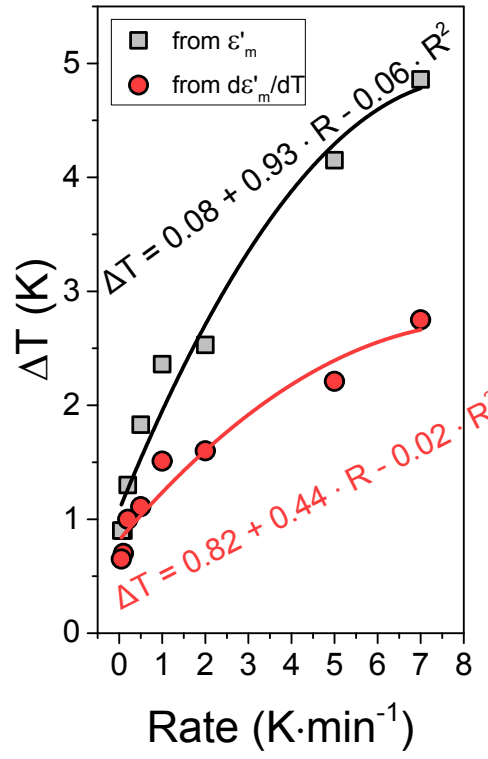

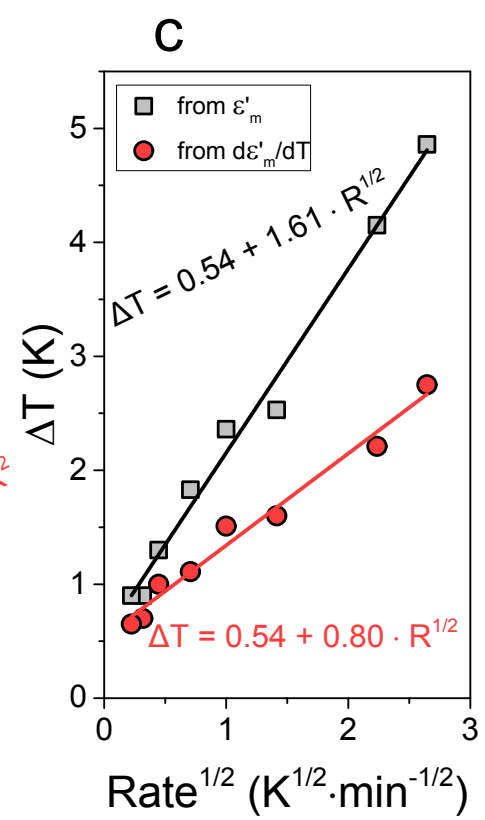

Figure S2. (a) Temperature dependence of the dielectric permittivity for 1-dodecanol confined in AAO templates with a pore diameter of $400 \mathrm{~nm}$ shown for different cooling rates. (b) Temperature interval, $\Delta T$, of the nematic phase plotted as a function of the cooling rate. $\Delta T$ is obtained either from the range of the bell-shaped permittivity or from the breadth of the first derivative of dielectric permittivity with respect to temperature. (c) Temperature interval of the nematic phase plotted as a function of the square root of rate.

The temperature range of the nematic phase was studied for 1-dodecanol confined in AAO templates with a pore diameter of $400 \mathrm{~nm}$ for different cooling rates. The temperature range, $\Delta T$, of the nematic phase (obtained either directly from the shape of permittivity or from the breadth of the first derivative of permittivity with respect to temperature) decreases with decreasing rate. However, a stable nematic phase exists even under quasi-static conditions (e.g. in the limit Rate $\rightarrow 0$ ). The temperature interval of the nematic phase can be parameterized by a polynomial function of the rate itself or as a linear function of the square root of rate. 
a

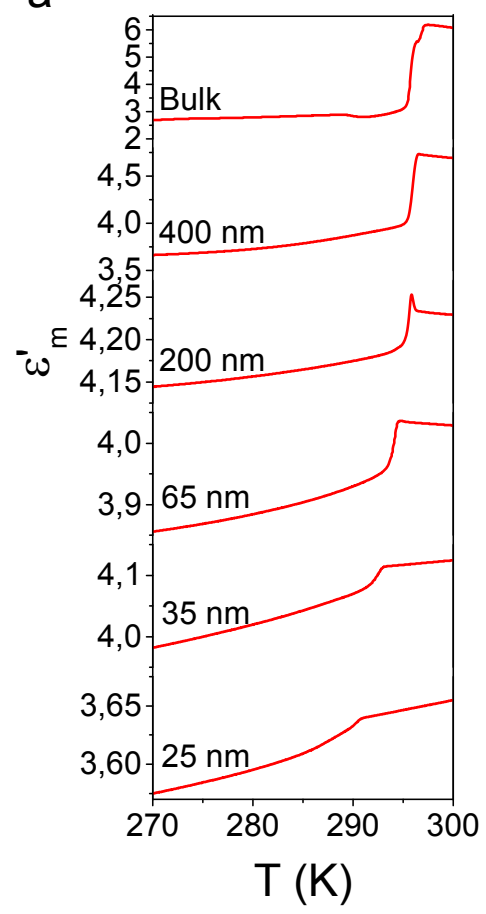

b

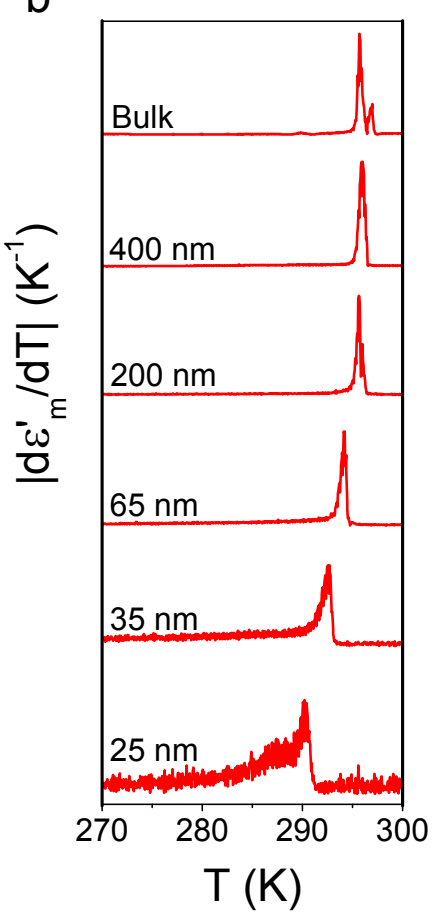

Figure S3. Dielectric permittivity of bulk and confined 1-dodecanol obtained on heating (frequency of $10^{5} \mathrm{~Hz}$, heating rate $\left.2 \mathrm{~K} \cdot \mathrm{min}^{-1}\right)$.

\section{Structure}

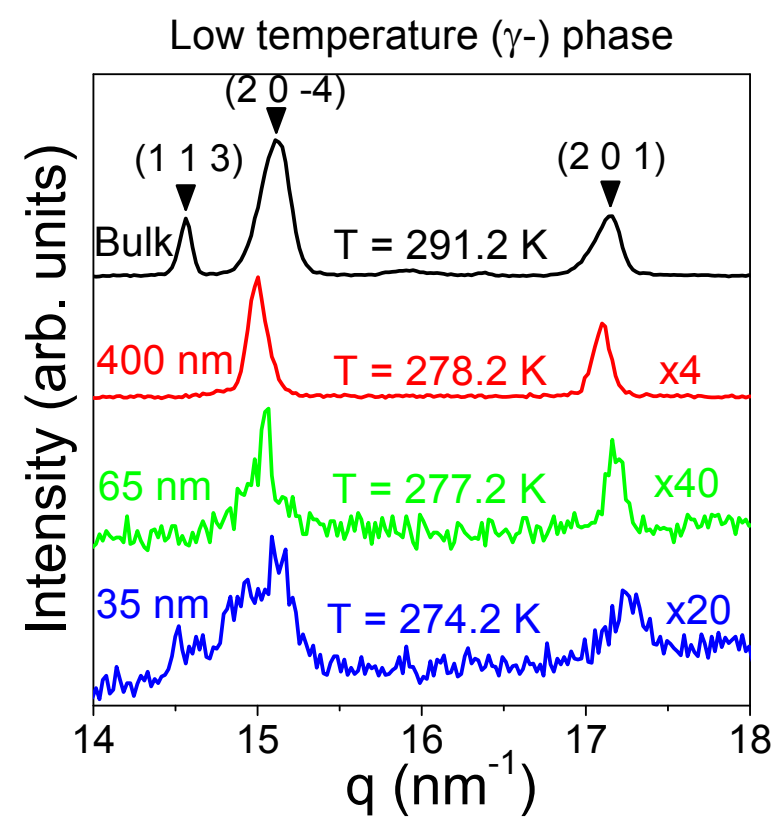

Figure S4. Low temperature $\gamma$-phase of bulk and confined 1-dodecanol. Measurements were carried out at the indicated temperatures. Patterns were multiplied by a factor as shown. 
In order to elucidate the origin of the step-like decrease in dielectric permittivity on cooling (Fig. 3) the following procedure was employed: AAO infiltrated samples with $400 \mathrm{~nm}$ and $65 \mathrm{~nm}$ pore diameters were first stored at $255.2 \mathrm{~K}$ for $1 \mathrm{~h}$ and subsequently submerged in liquid nitrogen for 10 min. XRD patterns were obtained at $273.5 \mathrm{~K}$ and $277.2 \mathrm{~K}$ for templates with pore diameters of 400 $\mathrm{nm}$ and $65 \mathrm{~nm}$, respectively. For $65 \mathrm{~nm}$ pores, the unit cell parameters corresponding to the monoclinic $\gamma$-phase were obtained before $\left(a=8.60 \AA, c=66 \AA\right.$ and $\left.\beta=118.4^{\circ}\right)$ and after quenching in LN2 $\left(a=8.545 \AA, c=66 \AA\right.$ and $\left.\beta=118.4^{\circ}\right)$. From the unit cell parameters at the two temperatures the thermal expansion coefficient of confined 1-dodecanol within AAO pores with a diameter of 65 $\mathrm{nm}$ along the $a$ axis was calculated $\left(\alpha_{a}=2.9 \times 10^{-4} K^{-1}\right)$. This value of the thermal expansion coefficient justifies the same crystal phase within the temperature range from $255.2 \mathrm{~K}$ to $277.2 \mathrm{~K}$. Hence, the small step-like decrease in dielectric permittivity is most likely reflecting the same monoclinic $\gamma$-phase. 